\title{
Involvement of cGMP in Nociceptive Processing by and Sensitization of Spinothalamic Neurons in Primates
}

\author{
Qing Lin, Yuan Bo Peng, Jing Wu, and William D. Willis \\ Department of Anatomy and Neuroscience, Marine Biomedical Institute, The University of Texas Medical Branch, \\ Galveston, Texas 77555-1069
}

Central sensitization of spinothalamic tract (STT) neurons in anesthetized monkeys after intradermal injection of capsaicin depends in part on disinhibition. Protein kinase $C$ is suggested to participate in this process. The present study shows that the nitric oxide-cGMP (NO-cGMP) signal transduction system also contributes to sensitization of wide dynamic range (WDR) STT neurons located in the deep dorsal horn. The NO-cGMP system was activated by microdialysis administration into the dorsal horn of 8-bromo-cGMP, an analog of cGMP. Sensitization of STT cells by 8-bromo-cGMP increased the responses of deep WDR STT cells to both weak and strong mechanical stimulation of the skin and simultaneously attenuated the inhibition of the same neurons produced by stimulation in the periaqueductal gray (PAG). In contrast, WDR STT cells in the superficial dorsal horn and high-threshold (HT) STT cells in superficial or deep layers showed reduced responses to mechanical stimulation of the skin after infusion of 8-bromo-cGMP, and PAG inhibition of these neurons was unaffected. Sensitization of STT cells and the attenuation of PAG inhibition induced by intradermal injection of capsaicin were prevented by preteatment of the dorsal horn with a guanylate cyclase inhibitor, $1 \mathrm{H}$-[1,2,4]oxadiazolo[4,3-a]quinoxalin-1-one. The results support the hypothesis that activation of the NO-cGMP signal transduction system contributes to the sensitization of WDR STT neurons in the deep dorsal horn and helps explain why intradermal capsaicin injections often fail to sensitize superficial and HT STT cells. The results also support the idea that sensitization of STT cells is produced in part by disinhibition.

Key words: PKG; nitric oxide; guanylate cyclase; capsaicin; sensitization; spinothalamic tract; periaqueductal gray; monkey
It has been proposed that nitric oxide (NO) contributes to the development of hyperalgesia in models of acute and chronic pain (Moore et al., 1991; Haley et al., 1992; Meller et al., 1992a, 1994; Coderre and Yashpal, 1994). The best understood trigger for NO formation in nervous tissue is the opening of NMDA receptor channels, activating NO synthase (NOS) in a $\mathrm{Ca}^{2+}$-dependent manner (MacDermott et al., 1986; Murase et al., 1986; Womack et al., 1988; Bredt and Snyder, 1989). NO then increases the intracellular level of cGMP through activation of soluble guanylate cyclase (Meller et al., 1992a,b; Meller and Gebhart, 1993). In the vascular and nervous systems, cGMP-dependent protein kinases serve as a major effector for NO and cGMP (Meller and Gebhart, 1993; Lincoln et al., 1994). Membrane-permeable cGMP analogs administered intrathecally produce hyperalgesia (Garry et al., 1994a). Furthermore, after intradermal injection of capsaicin, the mechanical allodynia and hyperalgesia are reversed by intraspinal administration of an inhibitor of PKG (Willis and Sluka, 1995). NMDA-induced hyperalgesia is also prevented by pretreatment of the spinal cord with a guanylate cyclase inhibitor (Meller et al., 1992b).

Our laboratory has demonstrated that excitatory amino acids (EAAs) and neuropeptides play an important role in the development and maintenance of central sensitization of primate spi-

Received Dec. 13, 1996; revised Feb. 10, 1997; accepted Feb. 12, 1997.

This work was supported by National Institutes of Health Grants NS09743 and NS11255. We thank Kelli Gondesen for expert technical assistance in preparation of the experimental animals and Griselda Gonzales for expert assistance with the illustrations.

Correspondence should be addressed to Dr. William D. Willis, Department of Anatomy and Neuroscience, Marine Biomedical Institute, The University of Texas Medical Branch, 301 University Boulevard, Galveston, TX 77555-1069.

Copyright (C) 1997 Society for Neuroscience $0270-6474 / 97 / 173293-10 \$ 05.00 / 0$ nothalamic tract (STT) neurons (Dougherty et al., 1992a,b, 1993, 1994, 1995; Dougherty and Willis, 1992; Sluka et al., 1992; Sorkin et al., 1992). Sensitization of STT cells can be produced by intradermal capsaicin injection or induction of acute arthritis (Simone et al., 1991; Dougherty and Willis, 1992; Dougherty et al., 1992a) and can be blocked by antagonists of NMDA or neurokinin receptors (Dougherty et al., 1992a, 1994). It seems likely that central sensitization of dorsal horn neurons is initiated by the release of EAAs and peptides in the dorsal horn and depends in part on enhanced responses to the synaptic release of EAAs by mechanoreceptive afferent fibers (Dougherty and Willis, 1992; Sluka et al., 1992; Sorkin et al., 1992; Dougherty et al., 1993, 1994, 1995; Neugebauer et al., 1995). On the other hand, we have reported recently that the inhibition of STT neurons induced by the activation of spinal glycine and GABA receptors is reduced when STT cells are sensitized after capsaicin injection or activation of protein kinase C (PKC) (Lin et al., 1996c). Additionally, we found that the inhibition of STT cells produced by stimulating the periaqueductal gray (PAG) is attenuated during central sensitization (Lin et al., 1996b). Because PAG inhibition involves activation of spinal glycine and GABA receptors (Sorkin et al., 1993; Lin et al., 1994), we hypothesize that disinhibition of STT cells might play a role in central sensitization, and that secondmessenger systems are involved in this process.

We have now investigated the role of the NO-cGMP signal transduction system in the central sensitization of primate STT neurons. The contribution of changes in spinal inhibition to the central sensitization that is produced by activation of PKG was also examined by testing the inhibitory effects of stimulation in the PAG on STT neurons. 
BACKGROUND
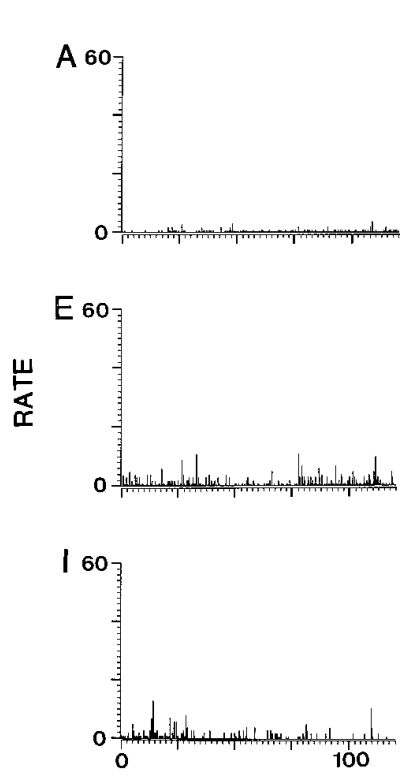

BRUSH

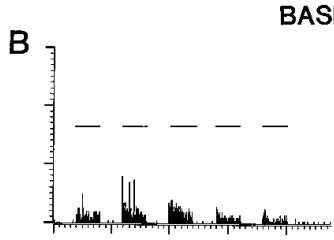

BASELINE
PRESS

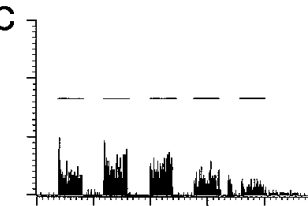

WITH 8-BROMO-cGMP
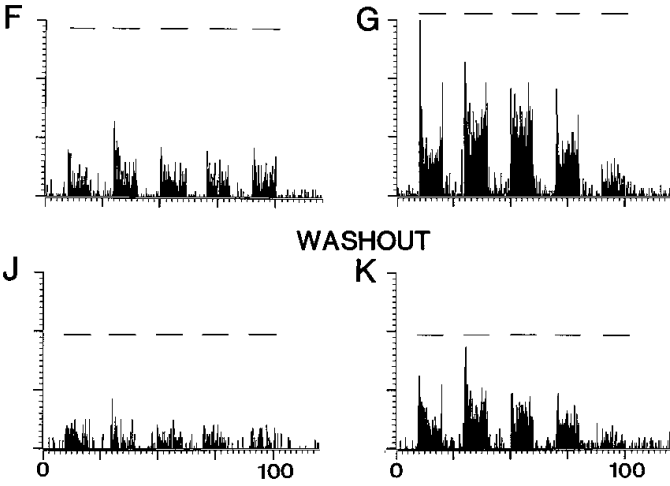

WASHOUT

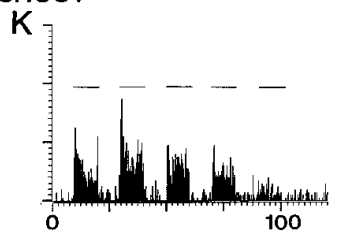

D
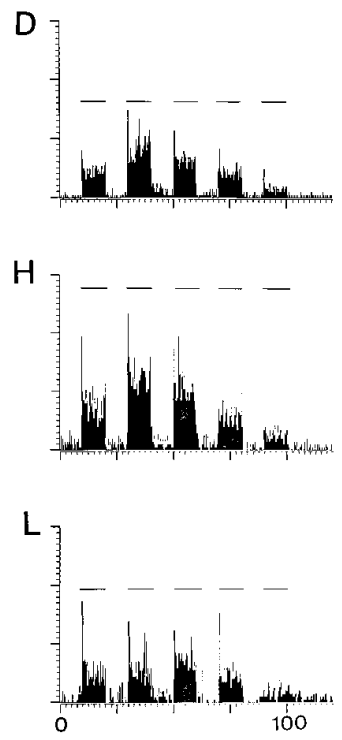

M

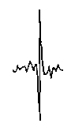

TIME (s)

Figure 1. Rate histograms represent the enhanced responses of a deep WDR STT cell during infusion of 8-bromo-cGMP into the spinal dorsal horn by microdialysis. $A-D$, Baseline background activity and responses to mechanical stimuli (BRUSH, PRESS, and PINCH). Horizontal lines above histograms show times of application of mechanical stimuli. $E-H$, Increased background activity and responses to cutaneous mechanical stimuli produced by 8-bromo-cGMP infusion. $I-L$, Background activity and responses to mechanical stimuli $1.5 \mathrm{hr}$ after the end of 8-bromo-cGMP administration. $M$, Spikes before, during, and after 8-bromo-cGMP.

A preliminary report has been published previously (Lin et al., 1996d).

\section{MATERIALS AND METHODS}

All experiments were approved by the local Animal Care and Use Committee and were consistent with the guidelines of the International Association for the Study of Pain and the National Institutes of Health Guide for the Care and Use of Laboratory Animals.

Young adult monkeys (Macaca fascicularis) weighing 1.5-3.1 kg were sedated with ketamine $(10 \mathrm{mg} / \mathrm{kg}$, i.m.), and then anesthetized with a mixture of nitrous oxide, oxygen, and halothane, followed by an intravenous dose of $\alpha$-chloralose $(60 \mathrm{mg} / \mathrm{kg})$. A stable level of anesthesia, as assessed by pupillary constriction, was maintained by intravenous infusion of pentobarbital sodium $\left(5 \mathrm{mg} \cdot \mathrm{kg}^{-1} \cdot \mathrm{hr}^{-1}\right)$. After a tracheotomy, the animal was artificially ventilated and paralyzed with gallamine triethiodide $(20 \mathrm{mg} / \mathrm{hr})$, which was also added to the infusion to maintain paralysis. End-tidal $\mathrm{CO}_{2}$ and rectal temperature were kept within physiological limits $\left(3.5-4.5 \%\right.$ and $\left.37 \pm 1{ }^{\circ} \mathrm{C}\right)$. A laminectomy was performed to expose the lumbar enlargement and a craniotomy was performed to allow stereotaxic placement of monopolar-stimulating electrodes into the ventral posterior lateral (VPL) nucleus of the thalamus and the PAG, respectively, as described in our previous experiments (Lin et al., 1994, 1996a).

The microdialysis fiber [150 $\mu \mathrm{m}$ inner diameter (i.d.), $9 \mu \mathrm{m}$ thick wall, $18 \mathrm{kDa}$ molecular cutoff, from Spectrum] was coated with silicone rubber except for a $1 \mathrm{~mm}$ gap intended to be the active dialysis zone for drug delivery within the spinal dorsal horn (Dougherty et al., 1992a). In each animal, two or three fibers were passed through the spinal cord with the dialysis zone in the dorsal horn of spinal cord segments $\mathrm{L}_{5}-\mathrm{L}_{7}$. The positions of fibers were usually located in laminae III-VI, as determined histologically (Sorkin et al., 1988). Artificial cerebrospinal fluid (ACSF), which contained (in mM): $151.1 \mathrm{Na}^{+}, 2.6 \mathrm{~K}^{+}, 0.9 \mathrm{Mg}^{2+}, 1.3 \mathrm{Ca}^{2+}, 122.7$ $\mathrm{Cl}^{-}, 21.0 \mathrm{HCO}_{3}^{-}, 2.5 \mathrm{HPO}_{4}{ }^{2-}$, and 3.87 glucose, was bubbled with $95 \%$ $\mathrm{O}_{2} / 5 \% \quad \mathrm{CO}_{2}$ before each experiment to reach a $\mathrm{pH}$ of 7.4, and was pumped continuously into the fibers with a flow rate of $5 \mu \mathrm{l} / \mathrm{min}$ during the control period and the period when the drug was washed out. Drugs delivered by microdialysis diffuse through at least one spinal segment, without significant leak into the blood and cerebrospinal fluid (Sluka and Westlund, 1993a).

A low-impedance (3-5 M $\Omega$ ) glass carbon filament electrode was used to record extracellular single-unit discharges in the dorsal horn of the lumbosacral enlargement. STT neurons were searched for in areas close to a microdialysis fiber (within $750 \mu \mathrm{m}$ ) to ensure that the drug would reach the cell. Unit activity of STT cells was monitored on storage and digital oscilloscopes and simultaneously fed to a window discriminator interfaced with a data analysis system (CED1401 plus linked to a Pentium computer using the Windows 95 operating system) for data storage and later analysis. Individual spike configuration and size were monitored continuously on a digital oscilloscope to confirm that the same cell was registered throughout the experiment. Figure $1 M$ shows an example of the spike shape of an STT neuron during an entire experiment. ST T cells were isolated using antidromic search stimuli $(0.75-1 \mathrm{~mA}, 200 \mu \mathrm{sec}$, at 0.3 $\mathrm{Hz}$ ) passed through the VPL electrode. The antidromic spikes occurred at fixed latency, showed collision with orthodromic spikes at appropriate intervals, and followed high-frequency $(333-500 \mathrm{~Hz})$ stimulus trains.

Second-messenger agents administered through a microdialysis fiber $(5 \mu \mathrm{l} / \mathrm{min})$ in the present study included a membrane-permeable analog of cGMP, 8-bromoguanosine-3',5'-cyclophosphate sodium (8-bromocGMP; RBI Inc.), and a selective inhibitor of soluble guanylate cyclase, 1 $\mathrm{H}-[1,2,4]$ oxadiazolo[4,3-a]quinoxalin-1-one [(ODQ) from Tocris Cookson, Inc., Bristol, UK]. ODQ was diluted in ACSF to a concentration of $1 \mathrm{~mm}$. The concentration of substances in the dialysis fluid was presumed to be approximately two orders of magnitude higher than the concentration that reached neurons in the dorsal horn. In the past we have studied the diffusion across the microdialysis fiber in vitro of several similar sized drugs with quite different chemical properties. The concentration ratio across the microdialysis fiber for all of these drugs was between 1 and $4 \%$ (Sluka and Westlund, 1993a; Sluka et al., 1993). Therefore, the final concentration of these two compounds at the site of tested neurons would be in the micromolar range, similar to that used in in vitro experiments, in which guanylate cyclase inhibitors have been shown to block selectively the NO-evoked increase in cGMP (Garthwaite et al., 1995). For example, the concentration of 8-bromo-cGMP used in this study was $10 \mathrm{~mm}$. This would result in delivery of a concentration of $10-100 \mu \mathrm{M}$ at the level of the neurons examined, which is comparable to the concentration used in in vitro experiments (Shibuki and Okada, 1991; Ito and Karachot, 1992).

When an STT neuron was isolated, the background activity and responses to mechanical stimuli were recorded. All cells were characterized by their responses to application of brush, pressure, and pinch to the skin of the hindlimb at the most responsive portion of the receptive field. The 
responses were used to classify the STT cells as low threshold (LT), wide dynamic range (WDR), or high threshold (HT) (Chung et al., 1986). Five sites across the receptive field were defined for delivery of three sets of mechanical stimuli. Each stimulus was applied for $10 \mathrm{sec}$ followed by a 10 sec pause before the next test site was stimulated. This sequence was followed until each kind of stimulus had been applied to all five sites. Innocuous BRUSH stimuli were delivered by repeated brushing in a stereotyped manner with a camel-hair brush. A firm pressure (PRESS stimulus) with a force of $144 \mathrm{~g} / \mathrm{mm}^{2}$, which is near pain threshold when placed on human skin, was applied to the skin of the receptive field by using a large clip. The small clip (PINCH) exerts a force of $538 \mathrm{~g} / \mathrm{mm}^{2}$ and is distinctly painful when applied to the skin. Care was taken to ensure that the BRUSH responses on each occasion were maximal and that the PRESS and PINCH stimuli were applied to the same marked site. Previous control experiments showed that repeated application of these nondamaging stimuli elicited consistent responses (Owens, 1991; Dougherty et al., 1992b). The inhibitory effects of electrically stimulating the PAG on the responses of STT cells to mechanical stimuli were tested by delivering $1 \mathrm{sec}$ trains of square pulses $(200 \mu \mathrm{sec}, 333 \mathrm{~Hz})$ repeated at $2 \mathrm{sec}$ intervals to the PAG at an intensity of $100-400 \mu \mathrm{A}$ while a $10 \mathrm{sec}$ mechanical stimulus was being applied to one point within the receptive field from which the maximal mechanical response was evoked. Stimulation sites in the PAG were located as described previously (Lin et al., 1994) and were determined histologically to be distributed mostly in the lateral or ventrolateral PAG at the level of the oculomotor or trochlear nuclei.

When control responses were recorded to all test stimuli, the infusion of ACSF was switched to ACSF containing 8-bromo-cGMP for 30-60 min. The tests were repeated during drug infusion. The perfusion fluid was then returned to normal ACSF and another set of tests was made 1-2 $\mathrm{hr}$ after drug application was stopped. For testing the effects of the guanylate cyclase inhibitor on central sensitization after intradermal injection of capsaicin, ST T cells were separated into two groups. One served as a control group in which no inhibitor was given before capsaicin was injected; for the other group, ODQ was infused for 30-60 min through a microdialysis fiber before capsaicin injection. Capsaicin was then injected intradermally at a site in the receptive field in the same way as that used in our previous studies (Lin et al., 1996b,c). In some cells, after the guanylate cyclase inhibitor had been washed out for a few hours, a second injection of capsaicin was made for the same cell. The responses were tested $15 \mathrm{~min}$ before and $15 \mathrm{~min}$ after the second capsaicin injection, respectively.

The mean total discharge rate in response to mechanical stimuli applied to the five points across the receptive field was summed, and then the background activity was subtracted to yield a net response value for each type of stimulus. The inhibitory effects of PAG stimulation on cutaneous mechanical stimulation-evoked responses were evaluated by calculating the percentage of inhibition of evoked activity. A repeatedmeasures ANOVA was used to test differences in the responses and the PAG inhibition in each group. If significance was obtained, post hoc testing with paired $t$ tests assessed differences across time. A value of $p<$ 0.05 was considered significant. All values are given as the mean \pm SE.

\section{RESULTS}

Recordings were made from a total of 48 STT neurons in 30 monkeys. The neurons included 43 WDR and 5 HT cells. No LT cells were encountered in the study. The depth of the neurons ranged from 972 to $2143 \mu \mathrm{m}$ below the dorsal surface of the spinal cord, which corresponds to locations within laminae I-VI (Owens, 1991). The mean depth of recording for the WDR neurons was $1501.3 \pm 43.2 \mu \mathrm{m}$, and that for the HT neurons was $1422.4 \pm 41.1$ $\mu \mathrm{m}$. Twenty-five cells were tested using 8-bromo-cGMP. These cells included 20 WDR neurons and 5 HT neurons. The remaining 23 cells, which were all classified as WDR neurons, were used in experiments to examine the effects of ODQ on the central sensitization produced by capsaicin injection.

\section{Changes in the responses of STT neurons to cutaneous mechanical stimuli produced by intraspinal administration of 8-bromo-cGMP}

Two distinctly different types of changes in the responses to cutaneous stimuli were seen in STT cells when the spinal dorsal horn was perfused with the same concentration of 8-bromocGMP. The direction of the changes was found to be dependent on how deep an STT cell was located in the dorsal horn and on what category the STT cell belonged to. For example, Figure 1 shows the responses recorded from an STT neuron that was categorized as a WDR cell located $1453 \mu \mathrm{m}$ from the surface of the spinal cord. When 8-bromo-cGMP was infused into the dorsal horn, the background activity and the responses of this neuron to the BRUSH, PRESS, and PINCH stimuli increased (compare Fig. $1 A-D$ with Fig. $1 E-H)$. The responses showed partial recovery $1.5 \mathrm{hr}$ after the infusion of 8-bromo-cGMP ended (Fig. 1I-L). Comparable observations were obtained for 12 other WDR STT neurons located in the deep dorsal horn.

In contrast, Figure 2 shows the responses of an STT cell that was also categorized as a WDR neuron, but that was located in the superficial dorsal horn. The recording depth was $1030 \mu \mathrm{m}$. Infusion of 8-bromo-cGMP resulted in an obvious decrease in the responses to BRUSH, PRESS, and $\mathrm{PINCH}$, with a slight decrease in background activity (compare Fig. $2 A-D$ with Fig. $2 E-H$ ). Partial recovery was observed $2 \mathrm{hr}$ after the termination of the infusion of 8-bromo-cGMP (Fig. 2I-L). Similar findings were obtained for six other WDR STT neurons located in the superficial dorsal horn. Five STT cells that were classified as HT neurons and located from 1288 to $1530 \mu \mathrm{m}$ below the surface of the spinal cord also showed reduced responses to mechanical stimuli when 8-bromo-cGMP was infused into the dorsal horn.

The changes in the responses to mechanical stimuli produced by 8-bromo-cGMP infusion are summarized in Figure 3. Because the same effect was obtained for both HT cells and superficial WDR neurons, the data from these cells were pooled. For the WDR cell population in the deep dorsal horn at depths ranging from 1352 to $2143 \mu \mathrm{m}$ that are presumably distributed within laminae V-VI $(n=13$; Fig. $3 A)$, microdialysis infusion of 8-bromo-cGMP resulted in a significant increase in background activity and in the responses to BRUSH, PRESS, and PINCH. In contrast, there was a significant reduction in the responses of HT cells $(n=5 ; 1288-1530 \mu \mathrm{m}$; Fig. $3 C)$ and superficial WDR neurons ( $n=7 ; 972-1288 \mu \mathrm{m}$; Fig. $3 C$ ) to BRUSH, PRESS, and PINCH without an obvious change in the background activity. After termination of the infusion, there was partial recovery of the responses.

\section{Changes in the inhibitory effects of stimulation in the PAG produced by intraspinal administration of 8-bromo-cGMP}

The effects of intraspinal infusion of 8-bromo-cGMP on the inhibition of responses to mechanical stimuli produced by stimulation in PAG were tested on the same groups of the cells that were used for examining the effects on mechanical stimulationevoked responses. Figure $4 A$ is an example of a recording from a deep WDR neuron $(1670 \mu \mathrm{m})$. The top row shows the inhibitory effects of PAG stimulation on background activity and on the responses to BRUSH, PRESS, and PINCH. The inhibition was consistent with findings in our previous work (Gerhart et al., 1984; Lin et al., 1994). The baseline percentage of inhibition of the evoked responses was $-45.4 \%$ for inhibition of BRUSH, $-70.6 \%$ for PRESS, and $-75.6 \%$ for PINCH. When the cell was sensitized by 8-bromo-cGMP infusion, the percentage of inhibition decreased to $-11.9 \%$ for BRUSH, $-39.6 \%$ for PRESS, and $-47.9 \%$ for PINCH (second row, Fig. $4 A$ ). Inhibition recovered partially $1.5 \mathrm{hr}$ after the end of drug infusion (bottom row, Fig. 4A). 
BACKGROUND

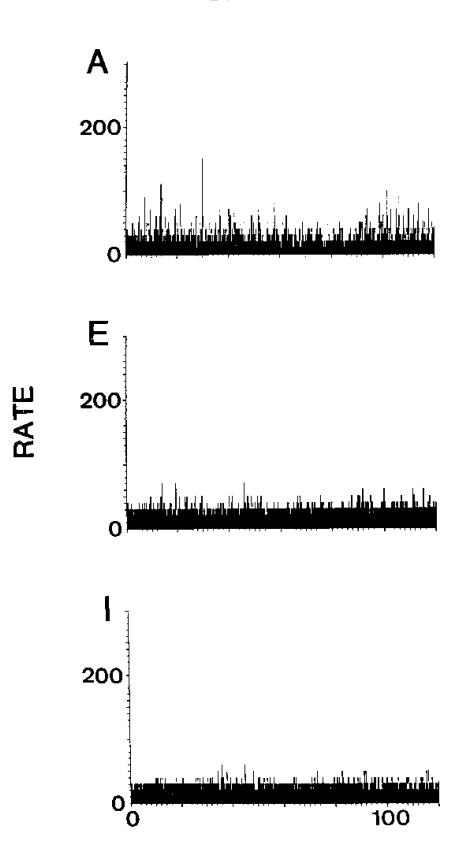

BRUSH

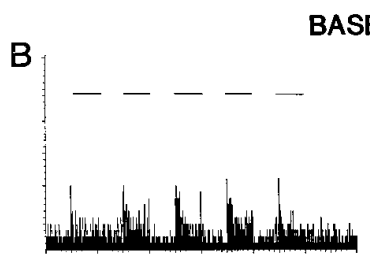

BASELINE

$\mathrm{F}$
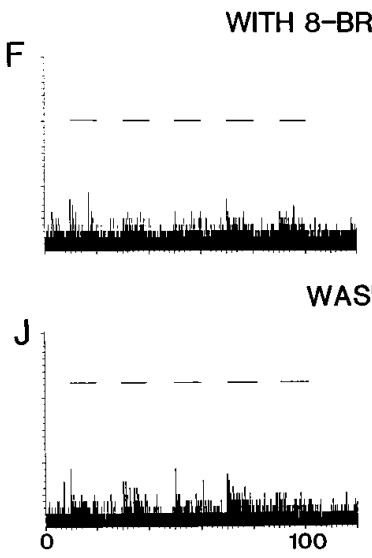

PRESS

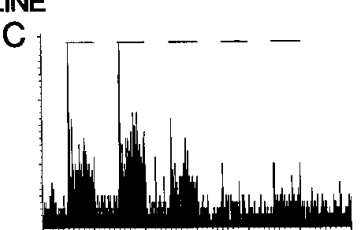

$\mathrm{G}$
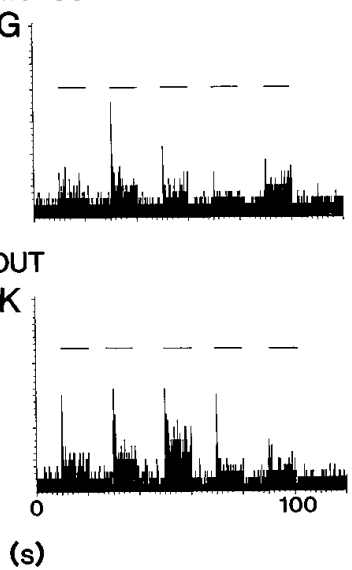

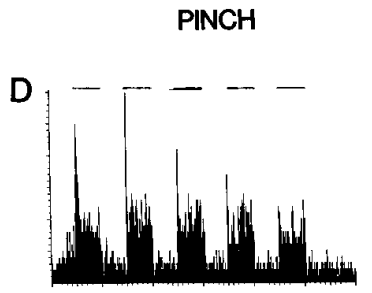

$\mathrm{H}$
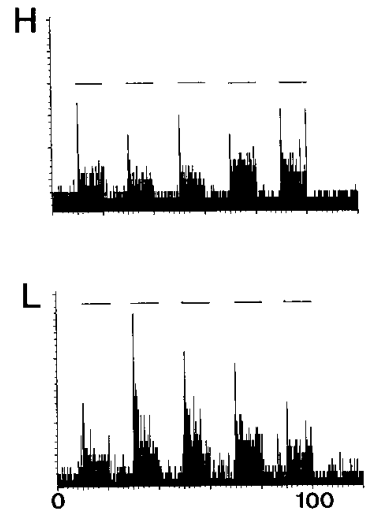

Figure 2. Rate histograms show the reduced responses of a superficial WDR cell produced by infusion of 8-bromo-cGMP within the spinal dorsal horn by microdialysis. $A-D$, Baseline background activity and responses to mechanical stimuli (BRUSH, PRESS, and PINCH). Horizontal lines above histograms show times of application of mechanical stimuli. $E-H$, Decreased responses to cutaneous mechanical stimuli produced by 8 -bromo-cGMP infusion. $I-L$, Background activity and responses to the mechanical stimuli $2 \mathrm{hr}$ after the end of 8-bromo-cGMP administration.

The effects of PAG stimulation were attenuated significantly during 8-bromo-cGMP application (Fig. 3B). Of 13 cells tested, a $>25 \%$ attenuation of the PAG-induced inhibition of responses to BRUSH, PRESS, and PINCH stimuli was obtained in 11 (84.6\%), $8(61.5 \%)$, and $9(69.2 \%)$ cells, respectively. Thus, the attenuation was particularly striking for the inhibition of the BRUSH responses $(p<0.001)$.

For HT and superficial WDR STT cells in which 8-bromocGMP infusion reduced responses to mechanical stimuli, 8-bromo-cGMP had no effect on the PAG-induced inhibition. An example of recordings from a superficial WDR neuron $(972 \mu \mathrm{m})$ is shown in Figure 4B. In some of these cells, a potentiation of PAG-induced inhibition was seen, but this did not reach statistical significance. A summary showing the lack of effect of 8-bromocGMP is provided by the bar graph in Figure $3 D$.

Effects of a guanylate cyclase inhibitor on sensitization of STT neurons and blockade of PAG-induced inhibition produced by intradermal injection of capsaicin

Capsaicin has been demonstrated to produce central sensitization of STT neurons to innocuous cutaneous stimuli and to attenuate the inhibition of STT neurons induced by stimulation of the PAG (Simone et al., 1991; Dougherty and Willis, 1992; Dougherty et al., 1992a; Lin et al., 1996b). In the present study, one group of WDR STT cells in the deep dorsal horn $(n=11)$ was pretreated with a guanylate cyclase inhibitor, ODQ, by microdialysis, before intradermal injection of capsaicin. The responses to mechanical cutaneous stimuli and PAG-induced inhibition were then compared with those seen in another group of STT cells $(n=12)$ without ODQ pretreatment (Fig. 5).

Figure $5 A$ summarizes the effects of ODQ on changes in the responses of STT cells to mechanical stimuli after intradermal injection of capsaicin. In the control group of STT cells, which were not pretreated with ODQ, as shown by the left pair of each set of bars (ACSF), a significant increase in the responses to BRUSH and PRESS (but not PINCH) was observed 15 min after capsaicin injection in all cells tested. In contrast, when ODQ was infused within the spinal dorsal horn while recordings were made from another group of STT cells, as shown by the right pair of each set of bars (ODQ), capsaicin injection failed to evoke an increase in any of the responses to mechanical stimuli.

Figure $5 B$ summarizes the effects of ODQ on changes in PAGinduced inhibition evoked by intradermal injection of capsaicin. Consistent with our previous experiments (Lin et al., 1996b), capsaicin injection resulted in a reduction in PAG-induced inhibition of the responses to mechanical stimuli in the control group of STT neurons that were not pretreated with ODQ. A $>25 \%$ blockade was seen in 10 cells ( 10 of $12,83.3 \%$ ), and the grouped effects reached statistical significance. This is shown by the left pair of each set of bars (ACSF). When the spinal dorsal horn was perfused with ODQ while recording from another group of cells, however, as shown by the right pair of each set of bars (ODQ), capsaicin-induced attenuation of inhibition induced by stimulation of the PAG was prevented completely. In addition, comparison of the baseline values for mechanical responses and PAG inhibition between the two groups of STT cells (open bars in each set of bars) reveals that ODQ itself had no significant effect on the cellular responses to mechanical stimuli or PAG inhibition.

For some STT neurons, it was possible to make two successive injections of capsaicin 2-3 hr apart. Examples are shown in Figures 6 and 7. The spinal dorsal horn was pretreated with ODQ for 30-60 min before the first capsaicin injection. ODQ itself did not have any obvious effect on mechanically evoked responses or PAG inhibition (second row, Figs. 6, 7). The first capsaicin injec- 

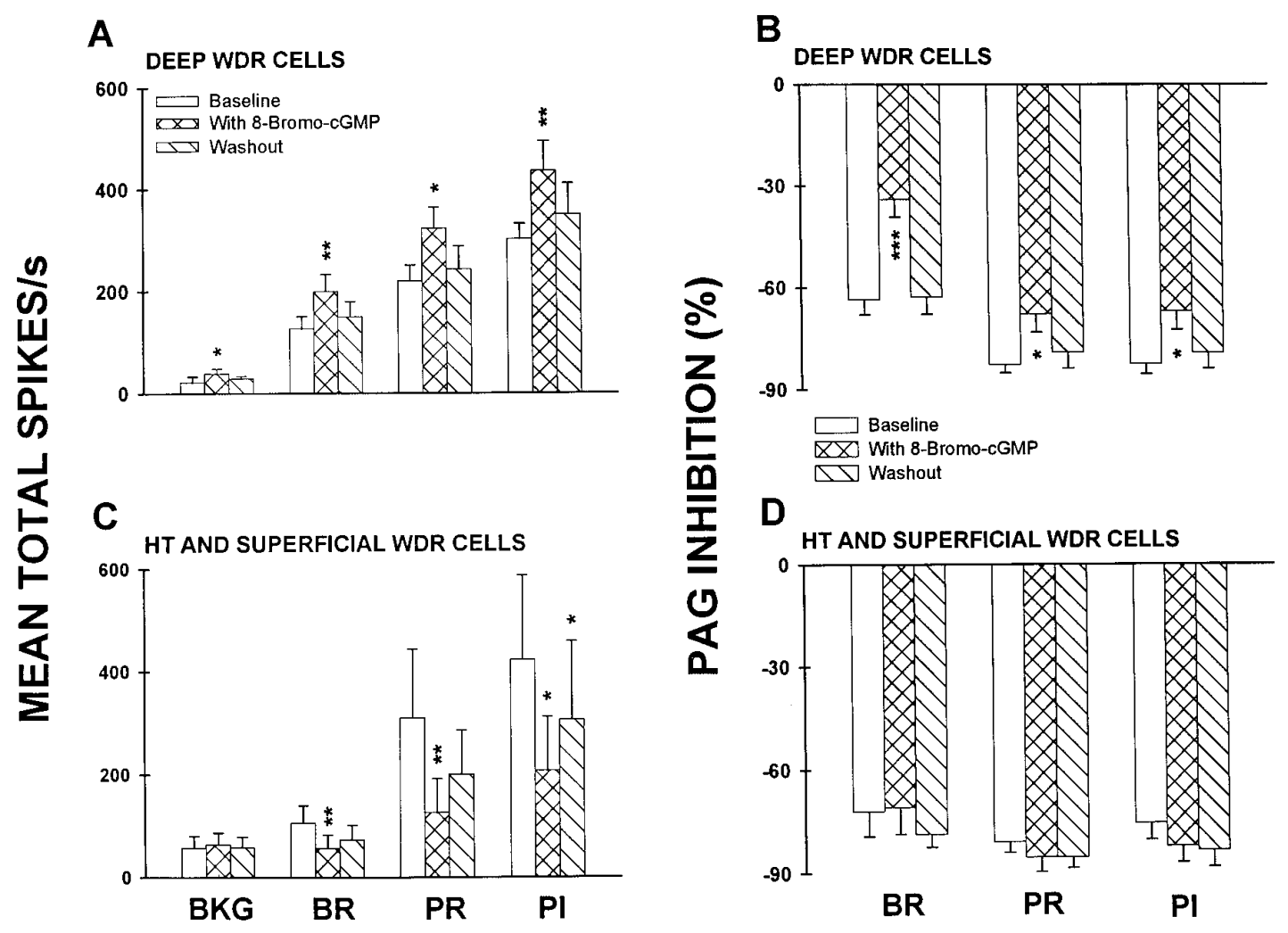

Figure 3. Bar graphs summarize the grouped data from STT neurons for background activity, responses to mechanical stimuli, and PAG inhibition when the spinal dorsal horn was perfused with 8-bromo-cGMP. Panels $A$ and $B$, Data from deep WDR STT cells $(n=13) ;$ panels $C$ and $D$, data from HT and superficial WDR STT cells ( $n=5$ for HT cells, $n=7$ for superficial WDR cells). $B K G$, Background activity; $B R$, BRUSH; PR, PRESS; PI, PINCH. * $p<$ $0.05 ; * p<0.01, * * * p<0.001$, compared with the baseline level.
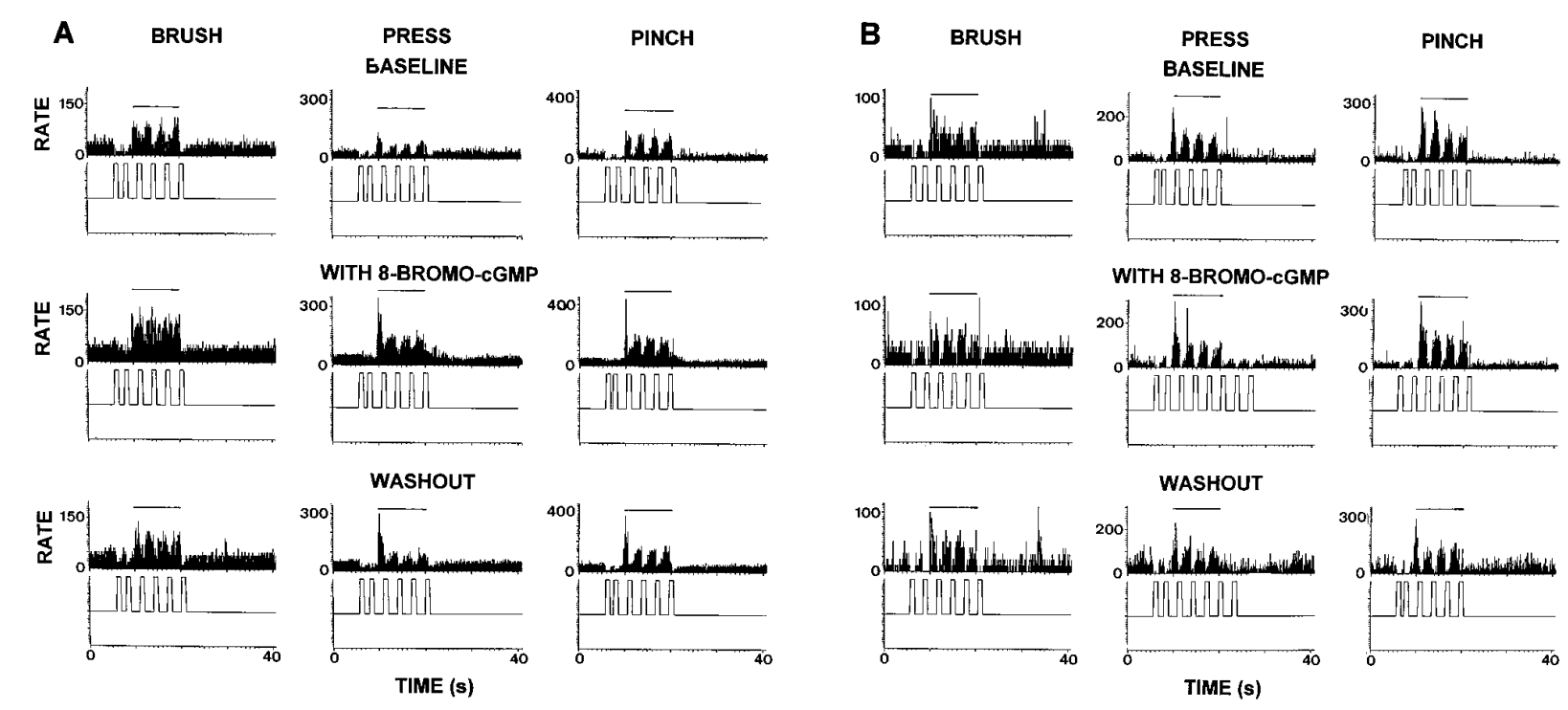

Figure 4. Changes in the inhibition of responses of a deep WDR STT neuron $(A)$ and a superficial WDR STT cell $(B)$ to mechanical stimuli produced by PAG stimulation when the spinal dorsal horn was perfused with 8-bromo-cGMP. Top row, Control effects of PAG stimulation; second row, PAG inhibition during 8-bromo-cGMP infusion; bottom row, PAG inhibition $1.5 \mathrm{hr}$ after the end of 8-bromo-cGMP infusion. Trains of stimuli applied in the PAG are indicated by upward-going square waves below each histogram.

tion, however, did not result in the sensitization of the cell to BRUSH and PRESS or any attenuation of PAG inhibition (third row, Figs. 6, 7), although the background activity was increased (third row, Fig. 6). ACSF was then infused to wash out any remaining drug for $1.5-2.0 \mathrm{hr}$, at which time the responses and
PAG inhibition were similar to the control values (fourth row, Figs. 6, 7). Increased responses to BRUSH and PRESS and a reduced PAG inhibition were then observed after the second dose of capsaicin was injected intradermally, indicating that the effects of ODQ were reversible (bottom row, Figs. 6, 7). 


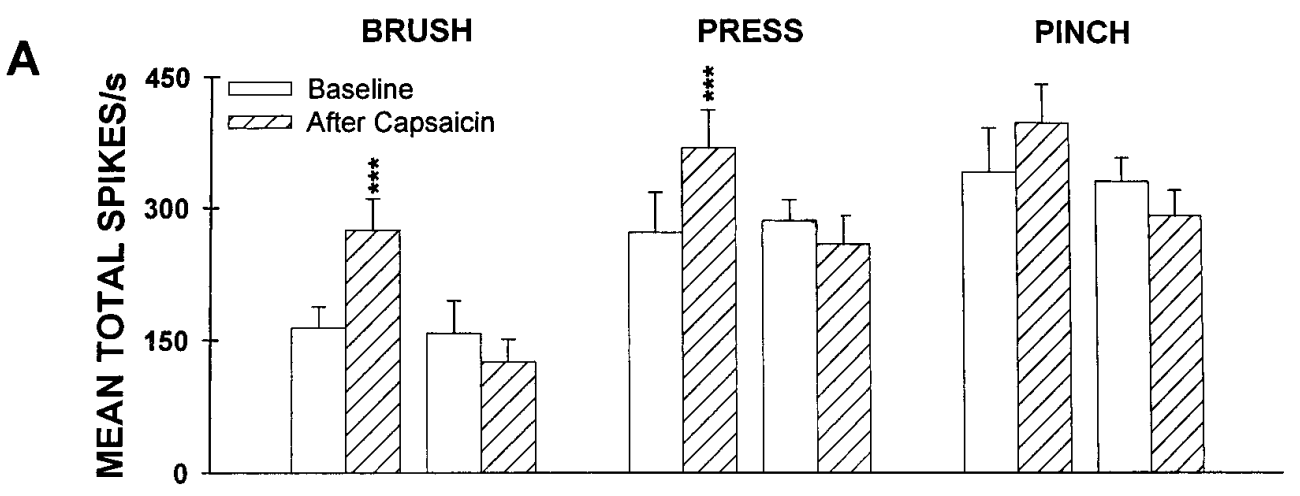

Figure 5. Bar graphs summarize the effects of ODQ infusion on the responses of STT cells to mechanical stimuli after capsaicin injection. The responses to mechanical stimulation are shown in panel $A$ and PAG inhibition in panel $B$. Cells were divided into two groups. Control responses after capsaicin injection from cells that were not pretreated with ODQ are shown by the left pair of each set of bars $(A C S F)$, and the responses after capsaicin injection when cells were pretreated with ODQ are shown by the right pair of each set of bars $(O D Q) .{ }^{* * p}<$ $0.01,{ }^{* * *} p<0.001$, compared with the pre-capsaicin baseline.

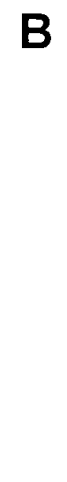

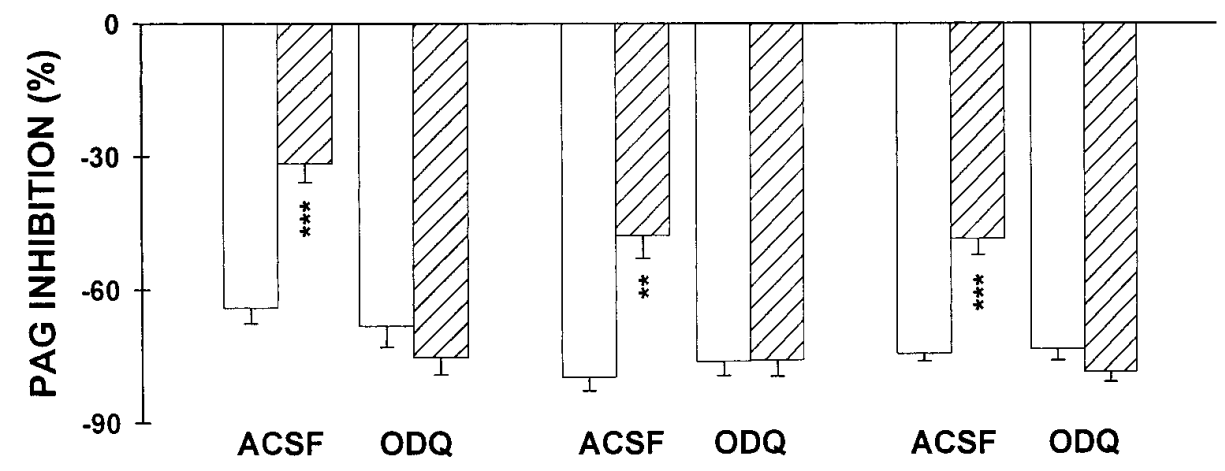

\section{DISCUSSION}

These experiments demonstrate that administration of 8-bromocGMP, a membrane-permeable derivative of cGMP that acts as an analog of cGMP, into the spinal dorsal horn produces longlasting changes in the responsiveness of STT neurons. The effects vary with the distribution and type of STT cells. STT neurons classified as WDR cells and distributed in the deep layers of the dorsal horn were sensitized during 8-bromo-cGMP infusion. 8-bromo-cGMP decreased the responses to both innocuous and noxious cutaneous stimuli of WDR STT neurons located more superficially and HT STT cells. The inhibition of BRUSH, PRESS, and PINCH responses induced by stimulation of the PAG was attenuated when deep WDR STT cells were sensitized by 8-bromo-cGMP infusion. 8-bromo-cGMP, however, produced no effect on PAG-induced inhibition of HT or superficial WDR STT cells. Furthermore, we found that the enhancement of responses to innocuous stimuli and the attenuation of PAG inhibition of these responses produced by intradermal injection of capsaicin could be prevented by pretreatment of the spinal dorsal horn with a guanylate cyclase inhibitor, ODQ.

Several lines of evidence suggest a role for the NO-cGMP signal transduction system in the development of hyperalgesia. Intrathecal injection of 8-bromo-cGMP resulted in thermal hyperalgesia (Garry et al., 1994a) and increased neuropathic pain-related autotomy (Niedbala et al., 1995). Iontophoretic application of 8-bromo-cGMP onto dorsal horn neurons preferentially enhances responses to noxious stimuli (Radhakrishnan and Henry, 1996). Moreover, an elevated level of immunoreactive cGMP in the dorsal horn was found when hyperalgesia developed after intraplantar injection of carrageenan (Garry et al., 1994b). Behavioral experiments by our group have shown that the allodynia after intradermal injection of capsaicin can be reversed by intraspinal administration of a PKG inhibitor (Willis and Sluka, 1995). These data are consistent with our present results.
We have demonstrated that central sensitization of STT neurons and persistent nociceptive behavior caused by capsaicin injection or arthritis depend on activity at both EAA and neurokinin receptors (Dougherty and Willis, 1992; Dougherty et al., 1992a,b, 1994, 1995; Sluka and Westlund, 1993a,b). It is known that the cGMP level is affected by excitatory pathways that release glutamate (Garthwaite, 1991; Meller and Gebhart, 1993). An increase in cGMP level within the cerebellum was elicited by exogenous glutamate both in vivo and in vitro (Ferrendelli et al., 1974; Mao et al., 1974; Garthwaite and Balázs, 1978). Glutamate increases cGMP content in cells through activation of NOS, which catalyzes the production of NO from L-arginine (Garthwaite and Balázs, 1978; Garthwaite et al., 1988; Bredt and Snyder, 1989, 1990). This process involves $\mathrm{Ca}^{2+}$ influx through receptor-operated ion channels, such as NMDA and some non-NMDA receptors (MacDermott et al., 1986; Garthwaite et al., 1988; Mayer and Miller, 1990; Lerea et al., 1992). The elevated level of NO caused by NOS activation in turn activates soluble guanylate cyclase, thus increasing the intracellular level of cGMP (Knowles et al., 1989; Southam et al., 1991; Bredt and Snyder, 1992).

Immunocytochemical studies have demonstrated NOS in the spinal cords of rats and monkeys (Dun et al., 1992; Zhang et al., 1993). NOS antagonists block nociceptive behavior induced by intraplantar injection of formalin (Moore et al., 1991; Coderre and Yashpal, 1994), decrease the discharges of dorsal horn neurons after formalin injection (Haley et al., 1992), reduce hyperalgesia in a model of neuropathic pain and after intrathecal administration of EAA and SP agonists (Meller et al., 1992a; Radhakrishnan et al., 1995), and prevent hyperalgesia after intrathecal application of NMDA (Kitto et al., 1992). PKG is selectively activated by cGMP or its analogs (Butt et al., 1992; Hartell, 1994). PKG exerts its modulatory effects by phosphorylation of proteins (Lincoln and Cornwell, 1993; Schmidt et al., 1993). Long-term depression of cerebellar Purkinje cells involves desen- 
BKG
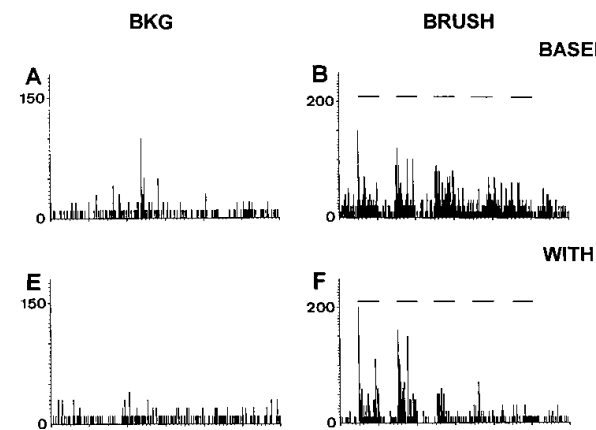

WITH ODQ
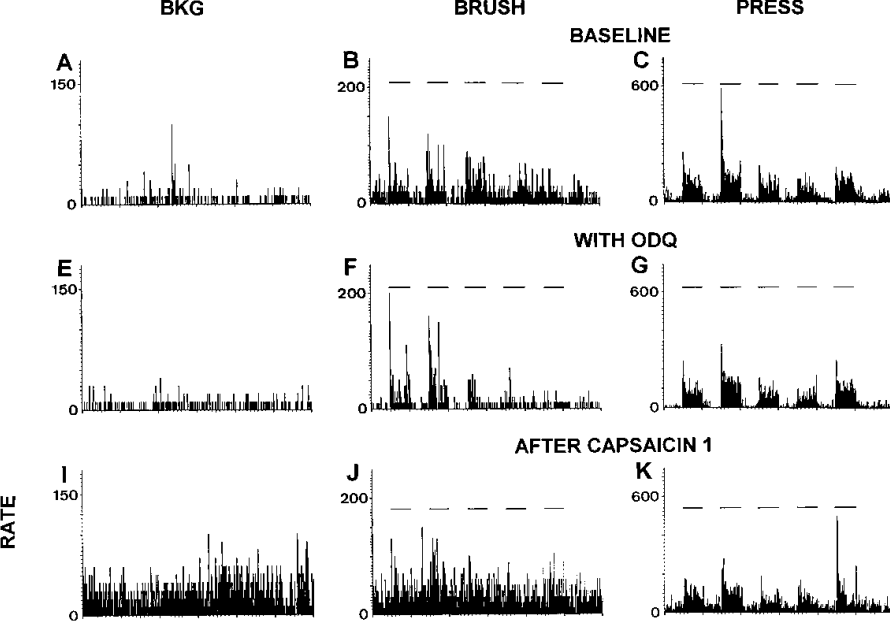

$O D Q$
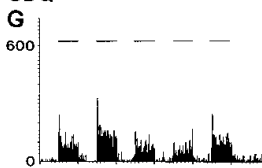

SAICIN 1
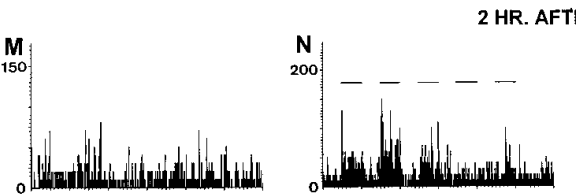

ER ODQ
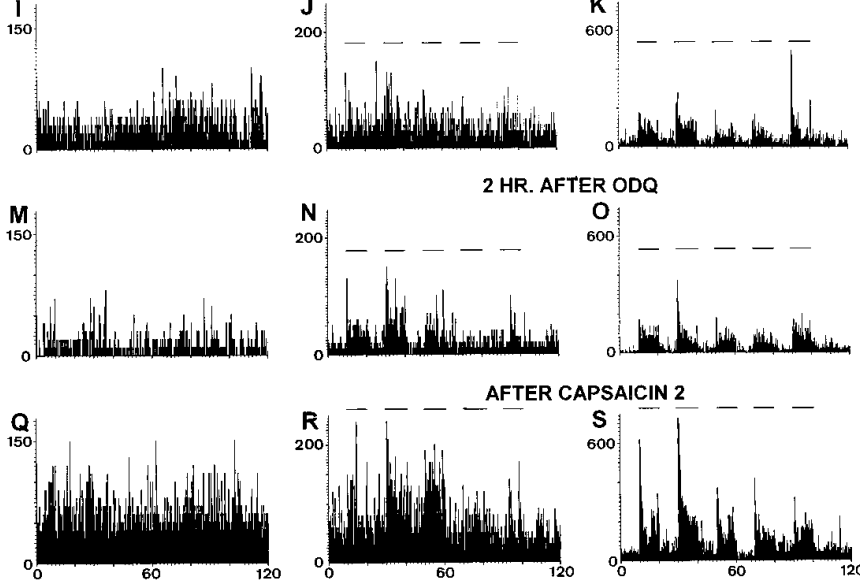

TIME (s)

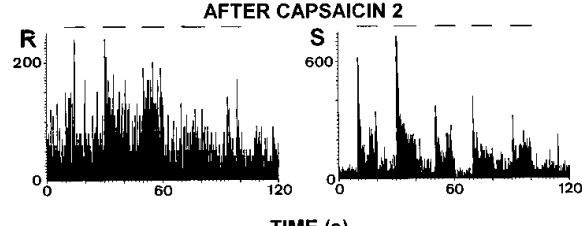

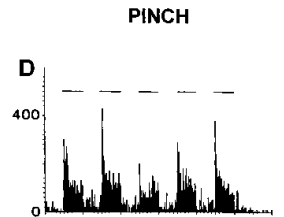
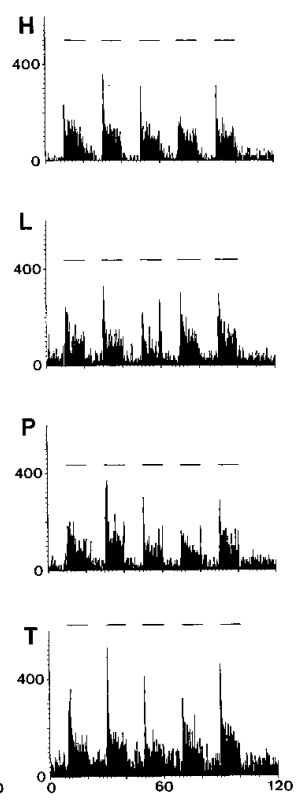

Figure 6. Rate histograms show the responses of an STT cell to mechanical cutaneous stimuli after intradermal injection of capsaicin with and then without pretreatment of spinal dorsal horn with ODQ, respectively. $A-D$, Baseline background activity and responses to mechanical stimuli (BRUSH, PRESS, and PINCH). Horizontal lines above histograms represent times of application of mechanical stimuli. $E-H$, Effects of infusion of ODQ within the dorsal horn. $I-L$, Effects of the first capsaicin injection during ODQ infusion by microdialysis. $M-P$, Two hours after the end of ODQ infusion. $Q-T$, Effects produced by the second capsaicin injection when ODQ was washed out. sitization of AMPA receptors by their phosphorylation after activation of PKG (Ito and Karachot, 1990, 1992). Recently, cGMPdependent protein kinase I was identified in neurons of spinal dorsal root ganglia and co-expressed with neuronal NOS, providing anatomical evidence that neuron-derived NO could serve to increase cGMP levels and activate cGMP-dependent protein kinase in primary afferent nociceptors (Qian et al., 1996). It can be predicted, therefore, that one of the routes by which the NOcGMP cascade mediates central sensitization of dorsal neurons is triggered by activation of EAA and neurokinin receptors during noxious stimulation.

We have reported evidence that activation of PKC enhances the responses of STT cells to peripheral stimulation and is involved in the capsaicin-induced sensitization of these neurons (Lin et al., 1996b). Examination of the differences in the effects of activators of PKC and PKG suggests that these protein kinases play somewhat different roles. Microdialysis administration of a phorbol ester, which activates PKC, enhances the responses of STT cells to BRUSH and PRESS, but not to PINCH (Paleček et al., 1994; Lin et al., 1996b). By contrast, spinal infusion of 8-bromo-cGMP, which activates PKG, was found in the present study to increase the responses of STT cells to all three intensities of mechanical cutaneous stimuli. Intradermal injection of capsaicin consistently increases the responses of STT cells to BRUSH and PRESS stimuli, but only in some STT cells does it increase the responses to PINCH. Thus, it appears that PKC is likely to produce the dominant effect in most STT cells after intradermal capsaicin injection, although in some neurons PKG may have a more prominent role. In future experiments, the effects of 8-bromocGMP on the responses of STT cells to noxious heat will be examined as a further test of differences between the actions of the PKC and PKG cascades.
It has been suggested recently that disinhibition of STT neurons in response to peripheral stimulation by desensitizing inhibitory amino acid (IAA) receptors, such as glycine and GABA receptors, also contributes to central sensitization (Lin et al., 1996c). Therefore, the change in PAG-induced inhibition can reflect indirectly a functional change in IAA activity because spinal glycine and GABA receptors have been demonstrated to help mediate PAG descending inhibition (Sorkin et al., 1993; Lin et al., 1994). In the present study, microdialysis administration of 8-bromo-cGMP reduced PAG inhibition of WDR ST T cells in the deep dorsal horn that underwent central sensitization, but not PAG inhibition of STT cells that were classified as HT or located in the superficial dorsal horn and that were not sensitized. These findings suggest a close association between central sensitization and a reduction in descending inhibition. The inhibitory action of GABA and glycine applied iontophoretically in the vicinity of STT cells is attenuated after intradermal injection of capsaicin or activation of PKC, suggesting a desensitization of IAA receptors on STT cells (Lin et al., 1996c). Presumably this desensitization could be produced by phosphorylation of these receptors by PKC and PKG. In other neural systems, protein kinases phosphorylate certain subunits of IAA receptors, decreasing inhibitory currents (Leidenheimer et al., 1992; Ragozzino and Eusebi, 1993; Rapallino et al., 1993; Vaello et al., 1994). Agents affecting the NO pathway reduce $\mathrm{Cl}^{-}$currents elicited by GABA in cerebellar granule cells (Zarri et al., 1994). Thus, it is presumed that an attenuation of tonic inhibition of dorsal horn neurons mediated by GABA or glycine receptors could play an important role in central sensitization. Part of these actions appear to be mediated by PKC (Lin et al., 1996b); the present study suggests that PKG may also contribute. In addition, there is an enhancement of the effects of EAAs on glutamate receptors (Chen and Huang, 1991; Dougherty 
BRUSH
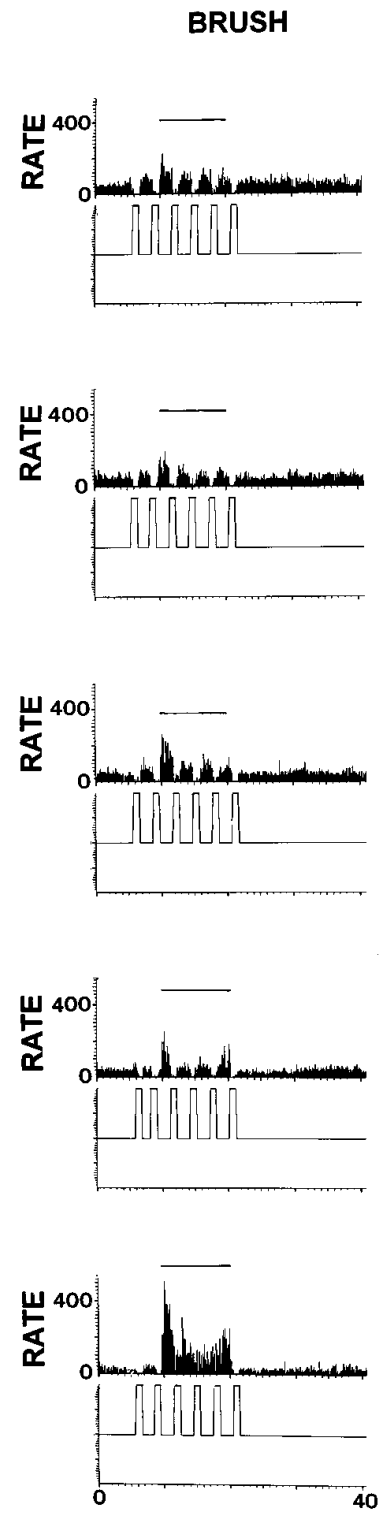

PRESS BASELINE

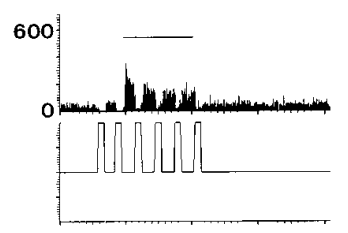

WITH ODQ

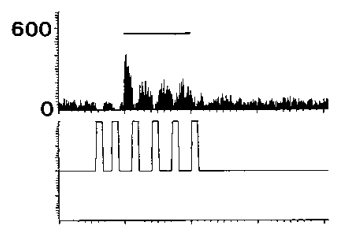

AFTER CAPSAICIN 1

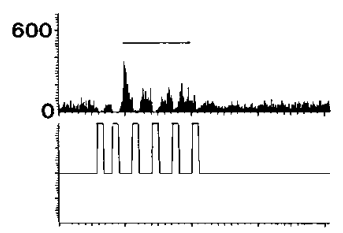

2 HR. AFTER ODQ

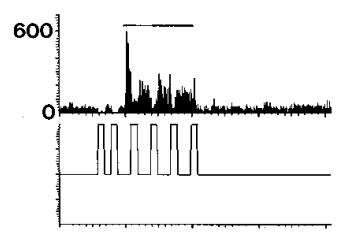

AFTER CAPSAICIN 2

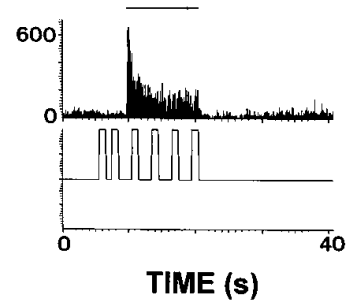

PINCH
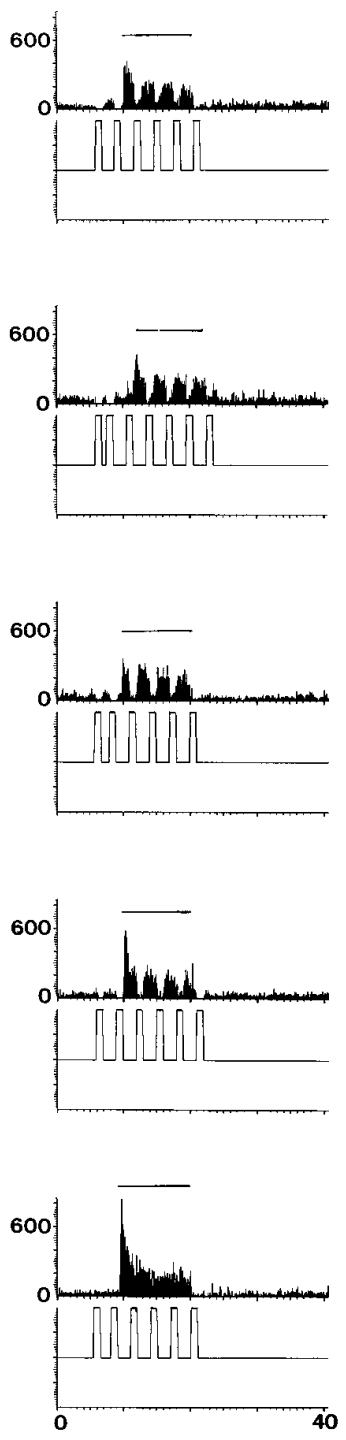

Figure 7. Rate histograms show changes in the attenuation of inhibitory effects of stimulation in the PAG on the responses of an STT cell to mechanical stimuli after intradermal capsaicin injection with and then without pretreatment of spinal cord with ODQ. Top row, Control effects of PAG stimulation; second row, effects of infusion of ODQ within the dorsal horn; third row, PAG inhibition 15 min after the first capsaicin injection during ODQ infusion; fourth row, PAG inhibition $2 \mathrm{hr}$ after the end of ODQ infusion; bottom row, PAG inhibition 15 min after the second capsaicin injection when ODQ was washed out. Trains of stimuli were applied in the PAG at times indicated by upward-going square waves below each histogram. Horizontal lines above histograms represent times of application of mechanical stimuli. and Willis, 1992; Dougherty et al., 1992b). We are currently investigating how activation of the NO-cGMP signal transduction system affects IAA receptors.

The same dose of 8-bromo-cGMP significantly reduced the responses of HT and superficial WDR STT cells to cutaneous mechanical stimuli in this study. One explanation could be that activation of PKG produces a functional change in GABA and glycine receptors on the HT and superficial WDR STT cells that is different from that on the deep WDR STT neurons. GABA and glycine receptors have been demonstrated to be distributed in the most layers of the spinal dorsal horn and an inhibitory effect was always seen in deep and superficial WDR STT cells, as well as HT cells, when these receptors were activated (Willcockson et al., 1984; Carlton et al., 1992; Mitchell et al., 1993; Bohlhalter et al., 1994; Lin et al., 1994, 1996a). Current information, however, fails to provide direct evidence that PKG produces differential effects on IAA receptors in different layers of dorsal horn. On the other hand, capsaicin injections have been shown to fail to sensitize significantly the cutaneous-evoked responses of HT STT cells, in contrast with the usual findings for WDR STT cells (Simone et al., 1991; Dougherty and Willis, 1992). Superficial STT neurons have small receptive fields for high-intensity stimuli (PINCH and heat) and weak responses to low-intensity stimuli (BRUSH), similar to HT cells in the deep dorsal horn (Chung et al., 1986; Al-Chaer et al., 1994; Rees et al., 1995). The responses of superficial dorsal horn neurons to noxious stimulation are facilitated by descending pathways that originate in brainstem nuclei, such as the anterior pretectal nucleus (APTN). Stimulation of the APTN produces antinociception and inhibition of the responses of the nociceptive cells located in deep layers of the dorsal horn (Al-Chaer et al., 1994; Rees et al., 1995). It has been proposed that noxious stimuli excite superficial neurons that activate brainstem nuclei, which in turn inhibit deep neurons of the dorsal horn to reduce the responses to noxious stimuli (McMahon and Wall, 1988; Rees et al., 1995). Therefore, it is reasonable to postulate that the inhibitory effects of cGMP on HT and superficial STT neurons might interfere with this positive feedback pathway and this would attenuate the descending inhibition of deep cells. This presumably 
could be another mechanism by which deep neurons are sensitized by the NO-cGMP pathway.

\section{REFERENCES}

Al-Chaer ED, Rees H, Tsuruoka M, Willis WD (1994) Facilitation of superficial STT cells by stimulation of the pretectal region in the primate. Soc Neurosci Abstr 20:548.

Bohlhalter S, Mohler H, Fritschy J (1994) Inhibitory neurotransmission in rat spinal cord: co-localization of glycine- and $\mathrm{GABA}_{\mathrm{A}^{-}}$receptors at GABAergic synaptic contacts demonstrated by triple immunofluorescence staining. Brain Res 642:59-69.

Bredt DS, Snyder SH (1989) Nitric oxide mediates glutamate-linked enhancement of cGMP levels in the cerebellum. Proc Natl Acad Sci USA 86:9030-9033.

Bredt DS, Snyder SH (1990) Isolation of nitric oxide synthase, a calmodulin-requiring enzyme. Proc Natl Acad Sci USA 87:682-685.

Bredt DS, Snyder SH (1992) Nitric oxide, a novel neuronal messenger. Neuron 8:3-11.

Butt E, Nolte C, Schulz S, Beltman J, Beavo JA, Jastorff B, Walter U (1992) Analysis of the functional role of cGMP-dependent protein kinase in intact human platelets using a specific activator 8-parachlorophenylthio-cGMP. Biochem Pharmacol 43:2591-2600.

Carlton SM, Westlund KN, Zhang D, Willis WD (1992) GABAimmunoreactive terminals synapse on primate spinothalamic tract cells. J Comp Neurol 322:528-537.

Chen L, Huang LM (1991) Sustained potentiation of NMDA receptormediated glutamate responses through activation of protein kinase $\mathrm{C}$ by a $\mu$ opioid. Neuron 7:319-326.

Chung JM, Surmeir DJ, Lee KH, Sorkin LS, Honda CN, Tsong Y, Willis WD (1986) Classification of primate spinothalamic and somatosensory thalamic neurons based on cluster analysis. J Neurophysiol 56:308-327.

Coderre TJ, Yashpal K (1994) Intracellular messengers contributing to persistent nociception and hyperalgesia induced by L-glutamate and substance $\mathrm{P}$ in the rat formalin pain model. Eur $\mathrm{J}$ Pharmacol 6:1328-1334.

Dougherty PM, Willis WD (1992) Enhanced responses of spinothalamic tract neurons to excitatory amino acids accompany capsaicin-induced sensitization in the monkey. J Neurosci 12:883-894.

Dougherty PM, Palcěk J, Paleǩová V, Willis WD (1992a) The role of NMDA and non-NMDA excitatory amino acid receptors in the excitation of primate spinothalamic tract neurons by mechanical, chemical, thermal, and electrical stimuli. J Neurosci 12:3025-3041.

Dougherty PM, Sluka KA, Sorkin LS, Westlund KN, Willis WD (1992b) Neural changes in acute arthritis in monkeys. I. Parallel enhancement of responses of spinothalamic tract neurons to mechanical stimulation and excitatory amino acids. Brain Res Rev 17:1-13.

Dougherty PM, Paleček J, Zorn S, Willis WD (1993) Combined application of excitatory amino acids and substance $\mathrm{P}$ produces long-lasting changes in responses of primate spinothalamic tract neurons. Brain Res Rev 18:227-246.

Dougherty PM, Paleček J, Palečková V, Willis WD (1994) Neurokinin 1 and 2 antagonists attenuate the responses and NK1 antagonists prevent the sensitization of primate spinothalamic tract neurons after intradermal capsaicin. J Neurophysiol 72:1464-1475.

Dougherty PM, Paleček J, Palečková V, Willis WD (1995) Infusion of substance $\mathrm{P}$ or neurokinin $\mathrm{A}$ by microdialysis alters responses of primate spinothalamic tract neurons to cutaneous stimuli and to iontophoretically released excitatory amino acids. Pain 61:411-425.

Dun NJ, Dun SL, Forstermann U, Tseng LF (1992) Nitric oxide synthase immunoreactivity in rat spinal cord. Neurosci Lett 147:217-220.

Ferrendelli JA, Chang MM, Kinscherf DA (1974) Elevation of cyclic GMP levels in central nervous system by excitatory and inhibitory amino acids. J Neurochem 22:535-540.

Garry MG, Abraham E, Hargreaves KM, Aanonsen LM (1994a) Intrathecal injection of cell-permeable analogs of cyclic $3^{\prime}, 5^{\prime}$-guanosine monophosphate produces hyperalgesia in mice. Eur $\mathrm{J}$ Pharmacol 260:129-131.

Garry MG, Richardson JD, Hargreaves KM (1994b) Carrageenaninduced inflammation alters the content of i-cGMP and i-cAMP in the dorsal horn of the spinal cord. Brain Res 646:135-139.

Garthwaite J, Balázs R (1978) Supersensitivity to the cyclic GMP response to glutamate during cerebellar maturation. Nature 275:328-329.

Garthwaite J, Charles SL, Chess-Williams R (1988) Endotheliumderived relaxing factors released on activation of NMDA receptors suggests role as intracellular messenger in the brain. Nature 336:385-388.

Garthwaite J (1991) Glutamate, nitric oxide and cell-cell signalling in the nervous system. Trends Neurosci 14:60-67.

Garthwaite J, Southam E, Boulton CL, Nielsen EB, Schmidt K, Mayer B (1995) Potent and selective inhibition of nitric oxide-sensitive guanylyl cyclase by $1 \mathrm{H}-[1,2,4]$ oxadiazolo[4,3-a]quinoxalin-1-one. Mol Pharmacol 48:184-188.

Gerhart KD, Yezierski RP, Wilcox TK, Willis WD (1984) Inhibition of primate spinothalamic tract neurons by stimulation in periaqueductal gray or adjacent midbrain reticular formation. $\mathrm{J}$ Neurophysiol 51:450-466.

Haley JE, Dickenson AH, Schachter M (1992) Electrophysiological evidence for a role of nitric oxide in prolonged chemical nociception in the rat. Neuropharmacology 31:251-258.

Hartell NA (1994) cGMP acts within cerebellar Purkinje cells to produce long term depression via mechanisms involving PKC and PKG. NeuroReport 5:833-836.

Ito M, Karachot L (1990) Messengers mediating long-term desensitization in cerebellar Purkinje cells. NeuroReport 1:129-132.

Ito M, Karachot L (1992) Protein kinases and phosphatase inhibitors mediating long-term desensitization of glutamate receptors in cerebellar Purkinje cells. Neurosci Res 14:27-38.

Kitto KF, Haley JE, Wilcox GL (1992) Involvement of nitric oxide in spinally mediated hyperalgesia in the mouse. Neurosci Lett 148:1-5.

Knowles RG, Palacios M, Palmer RM, Moncada S (1989) Formation of nitric oxide from L-arginine in the central nervous system: a transduction mechanism for stimulation of the soluble guanylate cyclase. Proc Natl Acad Sci USA 86:5159-5162.

Leidenheimer NJ, McQuilkin SJ, Hahner LD, Whiting P, Harris RA (1992) Activation of protein kinase C selectively inhibits the $\gamma$-aminobutyric acid $_{\mathrm{A}}$ receptor: role of desensitization. Mol Pharmacol 41:1116-1123.

Lerea LS, Butler LS, McNamara JO (1992) NMDA and non-NMDA receptor-mediated increase of c-fos mRNA in dentate gyrus neurons involves calcium influx via different routes. J Neurosci 12:2973-2981.

Lin Q, Peng YB, Willis WD (1994) Glycine and GABA $_{\mathrm{A}}$ antagonists reduce the inhibition of primate spinothalamic tract neurons produced by stimulation in periaqueductal gray. Brain Res 654:286-302.

Lin Q, Peng YB, Willis WD (1996a) Role of GABA receptor subtypes in inhibition of primate spinothalamic tract neurons: difference between spinal and periaqueductal gray inhibition. J Neurophysiol 75:109-123.

Lin Q, Peng YB, Willis WD (1996b) Possible role of protein kinase C in the sensitization of primate spinothalamic tract neurons. J Neurosci 16:3026-3034.

Lin Q, Peng YB, Willis WD (1996c) Inhibition of primate spinothalamic tract neurons by spinal glycine and GABA is reduced during central sensitization. J Neurophysiol 76:1005-1014.

Lin Q, Peng YB, Willis WD (1996d) The effects of 8-bromo-cGMP on the inhibition of primate spinothalamic neurons produced by stimulation in periaqueductal gray and by activation of spinal glycine and GABA receptors. 8th World Congress on Pain, Integration Association for the Study of Pain, pp 473-474 (Abstract).

Lincoln TM, Cornwell TL (1993) Intracellular cyclic GMP receptor proteins. FASEB J 7:328-338.

Lincoln TM, Komalavilas P, Cornwell TL (1994) Pleiotropic regulation of vascular smooth muscle tone by cyclic GMP-dependent protein kinase. Hypertension 23:1141-1147.

MacDermott AB, Mayer ML, Westbrook GL, Smith SJ, Barker JL (1986) NMDA-receptor activation increases cytoplasmic calcium concentration in cultured spinal cord neurons. Nature 321:519-522.

Mao CC, Guidotti A, Costa E (1974) The regulation of cyclic guanosine monophosphate in rat cerebellum: possible involvement of putative amino acid neurotransmitters. Brain Res 79:510-514.

Mayer ML, Miller RJ (1990) Excitatory amino acid receptors, second messengers and regulation of intracellular $\mathrm{Ca}^{2+}$ in mammalian neurons. Trends Pharmacol Sci 11:254-260.

McMahon SB, Wall PD (1988) Descending excitation and inhibition of spinal cord lamina I projection neurones. J Neurophysiol 59:1204-1219.

Meller ST, Pechman PS, Gebhart GF, Maves TJ (1992a) Nitric oxide mediates the thermal hyperalgesia produced in a model of neuropathic pain in the rat. Neuroscience 50:7-10.

Meller ST, Dykstra C, Gebhart GF (1992b) Production of endogenous nitric oxide and activation of soluble guanylate cyclase are required for 
$N$-methyl-D-aspartate-produced facilitation of the nociceptive tail flick reflex. Eur J Pharmacol 214:93-96.

Meller ST, Gebhart GF (1993) Nitric oxide (NO) and nociceptive processing in the spinal cord. Pain 52:127-136.

Meller ST, Cummings CP, Traub RJ, Gebhart GF (1994) The role of nitric oxide in the development and maintenance of the hyperalgesia produced by intraplantar injection of carrageenan in the rat. Neuroscience 60:367-374.

Mitchell K, Spike RC, Todd AJ (1993) An immunocytochemical study of glycine receptor and GABA in laminae I-III of rat spinal dorsal horn. J Neurosci 13:2371-2381.

Moore PK, Oluyomi AO, Babbedge RC, Wallace P, Hart SL (1991) $\mathrm{L}-\mathrm{N}^{\mathrm{G}}$-nitro arginine methyl ester exhibits antinociceptive activity in the mouse. Br J Pharmacol 102:198-202.

Murase K, Ryu PD, Randić M (1986) Substance P augments a persistent slow inward calcium-sensitive current in voltage-clamped spinal dorsal horn neurons of the rat. Brain Res 365:369-376.

Neugebauer V, Weiretter F, Schaible HG (1995) Involvement of substance $\mathrm{P}$ and neurokinin-1 receptors in the hyperexcitability of dorsal horn neurons during development of acute arthritis in rat's knee joint. J Neurophysiol 73:1574-1583.

Niedbala B, Sanchez A, Feria M (1995) Nitric oxide mediates neuropathic pain behavior in peripherally denervated rats. Neurosci Lett 188:57-60.

Owens CM (1991) Plastic changes in the responses of primate spinothalamic neurons. PhD thesis, University of Texas Medical Branch.

Paleček J, Palečková V, Dougherty PM, Willis WD (1994) The effect of phorbol esters on the responses of primate spinothalamic neurons to mechanical and thermal stimuli. J Neurophysiol 71:529-537.

Qian Y, Chao DS, Santillano DR, Cornwell TL, Nairn AC, Greengard P, Lincoln TM, Bredt DS (1996) cGMP-dependent protein kinase in dorsal root ganglion: relationship with nitric oxide synthase and nociceptive neurons. J Neurosci 16:3130-3138.

Radhakrishnan V, Yashpal K, Hui-Chan CW, Henry JL (1995) Implication of a nitric oxide synthase mechanism in the action of substance $\mathrm{P}$ : L-NAME blocks thermal hyperalgesia induced by endogenous and exogenous substance P in the rat. Eur J Pharmacol 7:1920-1925.

Radhakrishnan V, Henry JL (1996) Effects of 8-bromo cyclic guanosine $3^{\prime} 5^{\prime}$-monophosphate (cGMP) on the responses of spinal dorsal horn cells to peripheral noxious and non-noxious stimulation in cats. 8th World Congress on Pain, IASP, p 137 (Abstract).

Ragozzino D, Eusebi F (1993) Inhibition of GABA and glycine responses by glutamate in rat hippocampal neurons. Brain Res 628:115-120.

Rapallino MV, Cupello A, Hyd'en H (1993) The increase in $\mathrm{Cl}^{-}$permeation across the Deiters neuron membrane by GABA on its cytoplasmic side is abolished by protein kinase $\mathrm{C}$ activators. Cell Mol Neurobiol 13:547-558.

Rees H, Terenzi MG, Roberts MHT (1995) Anterior pretectal nucleus facilitation of superficial dorsal horn neurones and modulation of deafferentation pain in the rat. J Physiol (Lond) 489:159-169.

Schmidt HHHW, Lohmann SM, Walter U (1993) The nitric oxide and
cGMP signal transduction system: regulation and mechanism of action. Biochim Biophys Acta 1178:153-175.

Shibuki K, Okada D (1991) Endogenous nitric oxide release required for long-term synaptic depression in the cerebellum. Nature 349:326-328.

Simone DA, Sorkin LS, Oh U, Chung JM, Owens C, LaMotte RH, Willis WD (1991) Neurogenic hyperalgesia: central neural correlates in responses of spinothalamic tract neurons. J Neurophysiol 66:228-246.

Sluka KA, Dougherty PM, Sorkin LS, Willis WD, Westlund KN (1992) Neural changes in acute arthritis. III. Changes in substance P, calcitonin gene-related peptide and glutamate in the dorsal horn of the spinal cord. Brain Res Rev 17:29-38.

Sluka KA, Westlund KN (1993a) Centrally administered non-NMDA but not NMDA receptor antagonists block peripheral knee joint inflammation. Pain 55:217-225.

Sluka KA, Westlund KN (1993b) An experimental arthritis in rat: the effects on non-NMDA and NMDA receptor antagonists. Neurosci Lett 149:99-102.

Sluka KA, Willis WD, Westlund KN (1993) Joint inflammation and hyperalgesia are reduced by spinal bicuculline. NeuroReport 5:109-112.

Sorkin LS, Steinman JL, Hughes MG, Willis WD, McAdoo DJ (1988) Microdialysis recovery of serotonin released in spinal cord dorsal horn. J Neurosci Methods 23:131-138.

Sorkin LS, Westlund KN, Sluka KA, Dougherty PM, Willis WD (1992) Neural changes in acute arthritis in monkeys. IV. Time course of amino acid release into the lumbar dorsal horn. Brain Res Rev 17:39-50.

Sorkin LS, McAdoo DJ, Willis WD (1993) Raphe magnus stimulationinduced antinociception in the cat is associated with release of amino acids as well as serotonin in the lumbar dorsal horn. Brain Res 618:95-108.

Southam E, East SJ, Garthwaite J (1991) Excitatory amino acid receptors coupled to the nitric oxide/cyclic GMP pathway in rat cerebellum during development. J Neurochem 56:2072-2081.

Vaello ML, Ruiz-G'omez A, Lerma J, Mayor FJ (1994) Modulation of inhibitory glycine receptors by phosphorylation by protein kinase $\mathrm{C}$ and cAMP-dependent protein kinase. J Biol Chem 269:2002-2008.

Willcockson WS, Chung JM, Hori Y, Lee KH, Willis WD (1984) Effects of iontophoretically released amino acids and amines on primate spinothalamic tract cells. J Neurosci 4:732-740.

Willis WD, Sluka KA (1995) The role of G-proteins and protein kinases in allodynia induced by intradermal injection of capsaicin in the rat. Soc Neurosci Abstr 21:1408.

Womack MD, MacDermott AB, Jessell TM (1988) Sensory transmitters regulate intracellular calcium in dorsal horn neurons. Nature 334:351-353.

Zarri I, Bucossi G, Cupello A, Rapallino MV, Robello M (1994) Modulation by nitric oxide of rat brain $\mathrm{GABA}_{\mathrm{A}}$ receptors. Neurosci Lett 180:239-242.

Zhang X, Verge V, Wiesenfeld-Hallin Z, Ju G, Bredt D, Snyder SH, Hokfelt T (1993) Nitric oxide synthase-like immunoreactivity in lumbar dorsal root ganglia and spinal cord of rat and monkey and effect of peripheral axotomy. J Comp Neurol 335:563-575. 